\title{
Stem Damage Modifies the Impact of Wind on Norway Spruces
}

\author{
Guntars Snepsts ${ }^{1}$, Mara Kitenberga ${ }^{1, *} \mathbb{C}$, Didzis Elferts ${ }^{1,2} \oplus$, Janis Donis ${ }^{1}$ and Aris Jansons ${ }^{1} \mathbb{C}$ \\ 1 Latvian State Forest Research Institute, Silava, Rīgas Street 111, LV-2169 Salaspils, Latvia; \\ guntars.snepsts@silava.lv (G.S.); didzis.elferts@lu.lv (D.E.); janis.donis@silava.lv (J.D.); \\ aris.jansons@silava.lv (A.J.) \\ 2 Faculty of Biology, University of Latvia, Jelgavas Street 1, LV-1004 Rīga, Latvia \\ * Correspondence: mara.kitenberga@gmail.com
}

Received: 13 March 2020; Accepted: 17 April 2020; Published: 19 April 2020

\begin{abstract}
Bark stripping caused by cervids can have a long-lasting negative effect on tree vitality. Such trees of low vitality might be more susceptible to other disturbances. The amplifying effects of disturbance interactions can cause significantly more damage to forest ecosystems than the individual effects of each disturbance. Therefore, this study aimed to assess the impact of bark stripping (stem damage) on the probability of wind damage and snapping height for Norway spruces (Picea Abies (L.) H. Karst.). In this study, we used the Latvian National Forest Inventory data from the period 2004-2018. In the analysis, we used data based on 32,856 trees. To analyse the data, we implemented a Bayesian binary logistic generalised linear mixed-effects model and the linear mixed-effects model. Our results showed that stem damage significantly increased the probability of wind damage and affected the snapping height of Norway spruces. Similarly, root damage, the slenderness ratio, the stand age, the stand density, the soil type, and the dominant tree species had a significant influence on the probability of wind damage. In both periods, trees with stem damage had significantly $(p<0.05)$ higher probability (odd ratio 1.68$)$ to be wind damaged than trees without stem damage. The stem damaged Norway spruce trees snapped in the first $25 \%$ of the tree height, while trees without stem damage snapped around half $(50 \%)$ of the tree height. Our results show that stem damage significantly alters the effect of wind damage on Norway spruces, suggesting that such damage must be incorporated into wind-risk assessment models.
\end{abstract}

Keywords: wind damage; Norway spruce; snapping height; hemiboreal forests; bark stripping; stem damage

\section{Introduction}

Climate-driven alterations in natural disturbance regimes have profound, multi-layered effects on forest succession dynamics, regeneration patterns, carbon cycling, and other ecosystem services [1-4]. A worldwide increase in the severity and frequency of drought, windstorms, fires, and insect outbreaks is predicted under climate change [5-8]. Very noticeable changes in the disturbance regime are expected in northern coniferous forests [1,2], provoking prominent alterations in ecological and economic aspects.

In European forests, wind causes roughly half of all-natural disturbance damage $[9,10]$. Catastrophic (stand-replacing) damage to forests is usually caused by exceptionally strong winds, such as those in thunderstorms and extra-tropical cyclones [11,12]. However, daily wind gusts or peak winds, which are considerably weaker than discrete windstorm events, cause damage to forests year-round. Tree species composition, stand structure, age, the height/diameter ratio, and density, as well as management activities, fragmentation, topography, and soil conditions, have a substantial influence on the risks of wind damage at the forest landscape, stand, and tree levels [13-19]. 
Studies show that the influence of changes in the disturbance regime on forests will most likely be amplified by the interactions between different disturbance agents [1]. These types of interactions are called linked disturbances, when the legacy of previous disturbance affects the severity, likelihood, and/or extent of subsequent disturbance [20,21]. In Europe, windstorms, coupled with subsequent bark beetle outbreaks, are some of the most studied linked disturbances, which mostly negatively affect Norway spruce (Picea Abies (L.) H. Karst.) forests. In boreal and hemiboreal forests, Norway spruce is the most susceptible tree species to wind damage, due to lower stem resistance and/or shallower root system [13,22]. The European spruce bark beetle (Ips typographus) can easily breed on wind weakened spruce trees, and an outbreak can develop quickly $[6,23]$. Windstorm damage severity might also be amplified by proceeding drought [24] or snow [25,26].

In European northern coniferous forests, besides the bark beetle, a common biotic disturbance agent is the cervid-both the red deer (Cervus elaphus) and moose (Alces alces) varieties being the most widespread types in Europe $[27,28]$. They cause increasing damage in managed forests and nature protection areas $[29,30]$ due to their steadily increasing population density [31,32]. Browsing and bark stripping can have long-lasting negative effects on tree vitality and growth [28,33,34]. Wounds caused by cervids or forestry operations are usually located on the lower part of the tree trunk, which is also the most economically valuable, thus causing significant financial losses $[35,36]$. Through the wounds, decay-causing fungi infect the tree and spread, through stem and root contacts, into nearby trees [37], which increases their vulnerability to wind damage [38].

Economic losses, caused by wind disturbances, largely depend on the frequency and intensity of such events $[39,40]$. Generally, salvage-logging operations in disturbed areas are substantially more expensive and time-consuming than harvesting in undamaged stands [41]. The proportion of uprooted-to-snapped trees varies depending on windstorm characteristics, the season, and soil conditions [42-44]. Additionally, the snapping height considerably affects the assortment structure and, thus, the value of recovered timber [45]. However, no systematic studies characterise snapping height distribution and its causes [16]. Such information would be valuable for risk assessment and, thus, strategic forestry planning and post-disturbance management decision-making.

In developed mechanistic, empirical, and machine learning models for wind-risk assessment, a variety of abiotic/biotic top-down and bottom-up controls of wind damage have been implemented [46,47]. However, the importance of stem damage caused by cervids or mechanical damage on tree wind stability has not been addressed. Such information would allow for the more precisely prediction of wind damage risks [48], which is especially important during thinning or in continuous-cover silviculture systems, where individual trees are removed from the stand [49]. This study aimed to assess the impact of stem damage (bark stripping, mechanical damage) on the probability of wind damage and snapping height for Norway spruces. Considering the reduction of vitality for stem-damaged trees and the high probability of decay development, we hypothesised that this harm will substantially decrease wind stability. To test this hypothesis, we evaluated the influence of different tree- and stand-scale factors on the probability of wind damage for Norway spruces. Since bark stripping also alters wood properties at the wounded part of the stem [50], we hypothesised that for the stem-damaged trees, snapping height would be considerably lower, that is, close to the wounded part of the stem. To test this hypothesis, we estimated the influence of stem damage and other tree characteristics on the snapping height of Norway spruces.

\section{Materials and Methods}

\subsection{Study Area and Sample Design}

The study was carried out in the territory of Latvia, which is located in a hemiboreal forest zone in Northeastern Europe [51]. The Norway spruce is the third most common tree species in Latvia, comprising $17.6 \%$ of the total forested area [52]. In the period 1981-2010, the mean annual temperature in Latvia was $+6.4^{\circ} \mathrm{C}$, the coldest month was February $\left(-3.7^{\circ} \mathrm{C}\right)$ and the warmest was July $\left(+17.4{ }^{\circ} \mathrm{C}\right)$. 
The mean annual amount of precipitation was almost $700 \mathrm{~mm}$ according to the Latvian Environment, Geology, and Meteorology Centre's statistics.

In this study, we used the Latvian National Forest Inventory's (NFI) data collected in the period between 2004 and 2018. The NFI is based on a systematic grid of $4 \times 4 \mathrm{~km}$, and sampling plots are situated in a quadratic cluster of four [53] and re-measured every five years. Studies have shown that NFI data can be used to monitor forest health and to assess different disturbance agents' impacts on forest resources $[54,55]$. The size of the sampling plot was $500 \mathrm{~m}^{2}$, where all trees had a diameter, at the breast height $(\mathrm{DBH}$, measured at $1.3 \mathrm{~m})$, of $>14 \mathrm{~cm}$. In the middle of the large sampling plot, a subplot of $100 \mathrm{~m}^{2}$ was situated where trees with a DBH of $6.1-14.0 \mathrm{~cm}$ were measured [52]. For the analysis, we selected only Norway spruce trees with a diameter of above $14 \mathrm{~cm}$ (in total, 32,856 trees).

For each tree, the status was recorded during each re-measurement: live, partially damaged, or dead. For each dead tree, the mortality mode (snapped, uprooted, bark beetle infestation, harvested, fire) was recorded. In cases where the trees were dead, they were removed from further measurements. For the snapped trees, the height of the breakage was recorded.

For each live tree, signs of non-lethal damage caused by wind, water, animals, fire, fungi, insects, or mechanical damage from harvesting operations, as well as the damaged part of the tree (roots, stump, stem, crown, branches, leaves, buds) were recorded. The intensity of stem damage was recorded as percentage of the damaged stem circumference. In our analysis, stem damage intensity was divided in three groups (1. no damage; $2 . \leq 30 \% ; 3$. $>30 \%$ ). At the stand level, the forest site type according to National forest-site type typology [56] was recorded. In our analysis, we classified forest site types into five groups (mineral soil, wet mineral soil, peat soil, drained mineral soil, drained peat soil). These types are primarily divided based on soil moisture regime. For mineral soils, the rooting depth is unsaturated with water. For wet mineral soil, the rooting depth is seasonally saturated with water. For peat soils, the upper soil layer is compromised by least $30 \mathrm{~cm}$ thick peat material. The drained mineral soils before drainage were wet mineral soils, while drained peat soils before drainage were peat soils.

In our analysis, either uprooted or snapped trees were included as wind-damaged trees. Each tree has a unique ID code, measured first between the period 2004 to 2008, second between the 2009 and 2013 period, and third between the period 2014 to 2018. We combined the results of two measurement periods to assign the status of tree (live, dead, partially damaged). To the data of first measurement period (2004-2008) was added information about the tree status from the second re-measurement period (2009-2013). Similarly, this was done for the second period (2009-2013) where information about the tree status was added from the third (2014-2018) re-measurement period.

For each tree, we calculated the slenderness coefficient, defined as the ratio of mean height ${ }^{2} / \mathrm{DBH}$ $\left(h^{2} / d\right)[13]$. We calculated a relative snapping height as a percentage, which is the ratio of snapping height/ height of the tree. We calculated the social status coefficient of the tree, defined as the ratio of an individual DBH of a tree/maximal diameter $(\mathrm{d} / \mathrm{dmax})$ of the stand. All the stand properties and tree characteristics which were used in the models are summarised in Table 1. 
Table 1. Description of explanatory variables tested in the models. Number of observations for categorical variables; mean \pm standard deviation $(\mathrm{SD})$ for continuous variables. $\mathrm{P} 1$ - the first period; P2-the second period.

\begin{tabular}{|c|c|c|c|}
\hline Abbreviation & Description & Classes/Range & $\begin{array}{l}\text { Number of Observations/ } \\
\text { Mean } \pm \text { SD }\end{array}$ \\
\hline Root dam & $\begin{array}{l}\text { Root-stump damage } \\
\text { (roots and stump-up to } \\
30 \mathrm{~cm} \text { from root collar) }\end{array}$ & $\begin{array}{l}\text { 0-no damage } \\
\text { 1-damaged }\end{array}$ & $\begin{array}{l}\text { P1-27,490 } \\
\text { P2-26,727 } \\
\text { P1-120 } \\
\text { P2-135 }\end{array}$ \\
\hline Stem dam & Stem damage & $\begin{array}{l}\text { 0-no damage } \\
\text { 1-damaged }\end{array}$ & $\begin{array}{l}\text { P1-23,629 } \\
\text { P2-21,905 } \\
\text { P1-3981 } \\
\text { P2-4957 }\end{array}$ \\
\hline Age & Stand age (years) & 12 to $160+$ years & $\begin{array}{l}P 1-61.0 \pm 26.2 \\
P 2-62.9 \pm 27.1\end{array}$ \\
\hline Height & $\begin{array}{l}\text { Mean height of the } \\
\text { dominant canopy } \\
\text { trees }(\mathrm{m})\end{array}$ & $8-40$ & $\begin{array}{l}\mathrm{P} 1-22.1 \pm 5.85 \\
\mathrm{P} 2-22.8 \pm 5.91\end{array}$ \\
\hline Volume & $\begin{array}{l}\text { Mean standing volume } \\
\left(\mathrm{m}^{3} \mathrm{ha}^{-1}\right)\end{array}$ & $2.5-850$ & $\begin{array}{l}\mathrm{P} 1-291 \pm 143 \\
\mathrm{P} 2-304 \pm 152\end{array}$ \\
\hline Species & Dominant tree species & $\begin{array}{l}\text { Scots Pine (Pinus sylvestris L.) } \\
\text { Common Oak (Quercus robur L.) } \\
\text { Ash (Fraxinus excelsior L.) } \\
\text { Norway Spruce } \\
\text { Birch (Betula pendula Roth and B. pubescens Ehrh.) } \\
\text { Black alder (Alnus glutinosa (L.) Gaertn) } \\
\text { Aspen (Populus tremula L.) } \\
\text { Grey alder (Alnus incana (L.) Moench) }\end{array}$ & $\begin{array}{l}\text { P1-651, P2-567 } \\
\text { P1-19, P2-17 } \\
\text { P1-21, P2-7 } \\
\text { P1-849, P2-823 } \\
\text { P1-709, P2-675 } \\
\text { P1-126, P2-132 } \\
\text { P1-198, P2-173 } \\
\text { P1-110, P2-88 }\end{array}$ \\
\hline Number & $\begin{array}{l}\text { Stand density } \\
\left(\text { trees ha }^{-1}\right)\end{array}$ & $100-17,180$ & $\begin{array}{l}P 1-1682 \pm 1425 \\
P 2-1590 \pm 1327\end{array}$ \\
\hline Basal area & $\begin{array}{l}\text { Mean basal area of the } \\
\text { dominant canopy layer } \\
\left(\mathrm{m}^{2} \mathrm{ha}^{-1}\right)\end{array}$ & $0.7-77$ & $\begin{array}{l}\mathrm{P} 1-25.1 \pm 9.57 \\
\mathrm{P} 2-26.2 \pm 9.82\end{array}$ \\
\hline Management & Harvesting operations & $\begin{array}{l}\text { 1. thinned in the last } 5 \text { years } \\
\text { 2. no management in the last } 5 \text { years } \\
\text { 3. other management activity }\end{array}$ & $\begin{array}{l}\text { P1-0, P2-186 } \\
\text { P1-2683, P2-2211P1-0, } \\
\text { P2-95 }\end{array}$ \\
\hline Soil group & $\begin{array}{l}\text { Soil type (based on } \\
\text { moisture regime) }\end{array}$ & $\begin{array}{l}\text { 1. dry mineral soil } \\
\text { 2. wet mineral soil } \\
\text { 3. peat soil } \\
\text { 4. drained mineral soil } \\
\text { 5. drained peat soil }\end{array}$ & $\begin{array}{l}\text { P1-1259, P2-1145 } \\
\text { P1-300, P2-285 } \\
\text { P1-177, P2-166 } \\
\text { P1-571, P2-526 } \\
\text { P1-376, P2-360 }\end{array}$ \\
\hline \multirow{2}{*}{ Slenderness ratio } & \multirow{2}{*}{ Height $^{2} /$ diameter } & \multirow{2}{*}{$1.7-75.7$} & $P 1-21.9 \pm 5.52$ \\
\hline & & & $\mathrm{P} 2-20.2 \pm 5.15$ \\
\hline \multirow{2}{*}{$\mathrm{d} / \mathrm{dmax}$} & \multirow{2}{*}{$\begin{array}{l}\text { Diameter/maximal } \\
\text { diameter in stand }\end{array}$} & \multirow{2}{*}{$0.2-0.9$} & $\mathrm{P} 1-0.591 \pm 0.183$ \\
\hline & & & $\mathrm{P} 2-0.593 \pm 0.183$ \\
\hline \multirow[t]{2}{*}{ Break height } & \multirow{2}{*}{$\begin{array}{l}\text { Snapping height }(\mathrm{m}) \\
\text { from the root collar }\end{array}$} & \multirow{2}{*}{$1-24.5$} & $P 1-7.38 \pm 4.69$ \\
\hline & & & $\mathrm{P} 2-7.73 \pm 4.68$ \\
\hline Damage intensity & $\begin{array}{l}\text { The relative damaged } \\
\text { area of stem } \\
\text { circumference }(\%)\end{array}$ & $\begin{array}{l}\text { 0. no damage } \\
\text { 1. } \leq 30 \% \\
\text { 2. }>30 \%\end{array}$ & $\begin{array}{l}\mathrm{P} 1-356, \mathrm{P} 2-280 \\
\mathrm{P} 1-32, \mathrm{P} 2-18 \\
\mathrm{P} 1-33, \mathrm{P} 2-12\end{array}$ \\
\hline
\end{tabular}

\subsection{Data Analysis}

We used a Bayesian binary logistic generalised linear mixed-effects model (GLMM) as implemented in the R 3.6.2 [57] library brms [58] to assess the effects of stand and tree characteristics on the probability of wind damage. Tree IDs and sampling plot IDs were used as nested random effects to account for repeated measurements of individual trees and trees coming from the same sampling plot. All continuous variables (stand age, density, basal area, slenderness ratio, $d / d m a x$ ) were scaled. Scaling is done by dividing the (centered) values by their standard deviations. The number of iterations was set to 3500 for each of the four chains. The convergence of the model was assessed by Rhat values (all values were 1.00). Non-linear hypothesis testing of the brms library was used to compare the levels of significant factors. 
The effects of stand and tree characteristics on snapping height were assessed using a linear mixed-effects model (LMER) as implemented in the $\mathrm{R}$ library lme4 [59]. $p$-values were calculated by the lmerTest library [60]. The sampling plot ID was used as a random factor in the model. The Variance Inflation Factor (VIF) was used to assess the multicollinearity between explanatory variables. The variables were excluded from the model when the VIF exceeded 5. A post hoc test for the significant differences in factor levels was performed with the Emmeans library [61]. Model coefficients and credibility intervals were transformed to odds ratio value by exponentiating them.

To compare the number of wind-damaged trees between diameter classes, time periods and presence of old stem damage, data were aggregated at the sampling plot level for each factor combination by calculating the total number of trees and trees with wind damage. Subsequently, the Bayesian binary logistic GLMM model was developed and non-linear hypothesis testing was used to compare levels. In this model, the sampling plot ID was used as a random effect.

\section{Results}

Wind-damaged trees (uprooted or snapped) comprised $3.7 \%$ and $3.8 \%$ of all Norway spruces in the first and second five-year period, respectively. In both periods, on average, $71 \%$ of stem damage was caused by cervids. The remaining almost-30\% of stem damage arised from mechanical damage by forest machinery. In the first measurement period (2004-2008), 12.5\% of all trees had stem damage and, of them, during the second re-measurement, $1 \%$ were uprooted, $1.4 \%$ were snapped, and $3 \%$ were dead standing. In the second period (2009-2013), 14.4\% of all trees had stem damage and, of them, in the third re-measurement period, $1.5 \%$ were uprooted, $0.7 \%$ were snapped, and $1.8 \%$ were snags. In both periods, trees with stem damage had significantly $(p<0.05)$ higher probability to be wind damaged than trees without stem damage. In both periods, in the diameter classes $(16-21 \mathrm{~cm} ; 21.1-27 \mathrm{~cm}$; 27.1-33 cm), trees with stem damage had a significantly higher probability of wind damage than trees without stem damage (Table 2). For the largest diameter classes $(33.1-39 \mathrm{~cm} ; 39.1-45 \mathrm{~cm}$; $>45 \mathrm{~cm}$ ), the probability of wind damage between the stem damaged and undamaged trees was insignificant.

Table 2. Summary of wind-damaged trees based on stem damage and diameter class in two re-measurement periods.

\begin{tabular}{|c|c|c|c|c|c|c|}
\hline $\begin{array}{l}\text { Diameter Classes with } \\
\text { and without Stem Damage }\end{array}$ & Live & Wind Damage & $\begin{array}{l}\text { Damaged of } \\
\text { the Total, } \%\end{array}$ & Live & Wind Damage & $\begin{array}{l}\text { Damaged of } \\
\text { the Total, \% }\end{array}$ \\
\hline $16-21 \mathrm{~cm}$ diameter & 16,310 & 580 & 3.4 & 15,213 & 570 & 3.6 \\
\hline No damage & 14,049 & 452 & 3.1 & 12,326 & 418 & 3.3 \\
\hline Damaged & 2261 & 128 & 5.4 & 2887 & 152 & 5.0 \\
\hline $21.1-27 \mathrm{~cm}$ diameter & 5936 & 235 & 3.8 & 6148 & 247 & 3.9 \\
\hline No damage & 5005 & 185 & 3.6 & 5008 & 184 & 3.5 \\
\hline Damaged & 931 & 50 & 5.1 & 1140 & 63 & 5.2 \\
\hline $27.1-33 \mathrm{~cm}$ diameter & 2674 & 123 & 4.4 & 2827 & 114 & 3.9 \\
\hline No damage & 2284 & 98 & 4.1 & 2384 & 92 & 3.7 \\
\hline Damaged & 390 & 25 & 6.0 & 443 & 22 & 4.7 \\
\hline $33.1-39 \mathrm{~cm}$ diameter & 1110 & 55 & 4.7 & 1079 & 53 & 4.7 \\
\hline No damage & 975 & 44 & 4.3 & 919 & 45 & 4.7 \\
\hline Damaged & 135 & 11 & 7.5 & 160 & 8 & 4.8 \\
\hline $39.1-45 \mathrm{~cm}$ diameter & 404 & 25 & 5.8 & 404 & 26 & 6.0 \\
\hline No damage & 359 & 21 & 5.5 & 343 & 23 & 6.3 \\
\hline Damaged & 45 & 4 & 8.2 & 61 & 3 & 4.7 \\
\hline$>45.1 \mathrm{~cm}$ diameter & 207 & 13 & 5.9 & 226 & 10 & 4.2 \\
\hline No damage & 194 & 12 & 5.8 & 200 & 8 & 3.8 \\
\hline Damaged & 13 & 1 & 7.1 & 26 & 2 & 7.1 \\
\hline
\end{tabular}


The GLMM model showed that, at the individual tree-level, vulnerability to wind damage was significantly affected by seven factors (Table 3). Vulnerability to wind damage was significantly increased by root (odd ratio 26.41 (CI: 15.05-47.01)) and stem damage (odd ratio 1.68 (CI: 1.41-2.00)), as well as by stand age (Figure 1). The susceptibility of wind damage decreased with an increasing stand density (Figure 2) and slenderness ratio $\left(\mathrm{h}^{2} / \mathrm{d}\right)$ (Figure 3$)$. The vulnerability of wind damage was significantly lower on wet mineral soils (odd ratio 0.50 (CI: 0.32-0.76)), peat (odd ratio 0.40 (CI: 0.21-0.75)), drained mineral (odd ratio 0.57 (CI: 0.40-0.79)), drained peat (odd ratio 0.64 (CI: 0.43-0.92)) in comparison to the dry mineral soil group. Compared to pine (reference level) dominated stands, spruce (odd ratio 3.80 (CI: 2.60-5.61)), birch (odd ratio 1.68 (CI: 1.12-2.56)), black alder (odd ratio 7.46 (CI: 3.84-14.83)), aspen (odd ratio 2.07 (CI: 1.17-3.61)), and grey alder (odd ratio 2.47 (CI: 1.02-5.67)) dominated stands had significantly higher susceptibility of wind damage, while oak (odd ratio 0.37 (CI: 0.05-2.43)) and ash (odd ratio 2.10 (CI: 0.51-8.33)) dominated stands did not significantly differ from Scots pine dominated stands. In stands dominated by broadleaves—birch, black alder, aspen, grey alder and ash-approximately $\sim 21 \%$ of all Norway spruce trees had stem damage, while in stands dominated by Scots pine, Norway spruce and common oak had a considerably lower proportion—approximately $\sim 14 \%$ of all Norway spruce trees had stem damage.

Table 3. Estimates and credibility intervals of the full generalised linear mixed-effects model (GLMM) model. Est. Error-SD of posterior distribution; CI-lower and upper limits of the credibility interval. For the factor variables, the estimate shows a difference to the reference level (dominant tree species—pine, management—none, soil group—dry mineral soil).

\begin{tabular}{lllll}
\hline Variable & Estimate & Est. Error & $\mathbf{1 - 9 5 \% ~ C I ~}$ & $\mathbf{u - 9 5 \% ~ C I ~}$ \\
\hline Intercept & -7.20 & 0.29 & -7.79 & -6.64 \\
Soil group & & & & \\
Wet mineral soil & -0.69 & 0.22 & -1.13 & -0.27 \\
Peat soil & -0.91 & 0.32 & -1.55 & -0.29 \\
Drained mineral soil & -0.57 & 0.17 & -0.92 & -0.24 \\
Drained peat soil & -0.45 & 0.19 & -0.84 & -0.08 \\
Damaged root & 3.27 & 0.29 & 2.71 & 3.85 \\
Damaged stem & 0.52 & 0.09 & 0.35 & 0.69 \\
Stand age & 0.47 & 0.08 & 0.31 & 0.62 \\
Species: & & & & \\
Oak & -1.00 & 0.97 & -2.95 & 0.89 \\
Ash & 0.74 & 0.71 & -0.67 & 2.12 \\
Spruce & 1.34 & 0.19 & 0.96 & 1.72 \\
Birch & 0.52 & 0.21 & 0.11 & 0.94 \\
Black alder & 2.01 & 0.35 & 1.35 & 2.70 \\
Aspen & 0.73 & 0.29 & 0.16 & 1.28 \\
Grey alder & 0.90 & 0.44 & 0.02 & 1.74 \\
Density & -0.37 & 0.07 & -0.51 & -0.23 \\
Basal area & 0.14 & 0.07 & -0.00 & 0.27 \\
Harvesting operations & & & & \\
Other management activity & -0.20 & 0.27 & -0.74 & 0.33 \\
Thinning in the last 5 years & 0.24 & 0.23 & -0.21 & 0.69 \\
h ${ }^{2}$ d & -1.20 & 0.07 & -1.34 & -1.07 \\
d/dmax & 0.05 & 0.04 & -0.04 & 0.13 \\
\hline
\end{tabular}




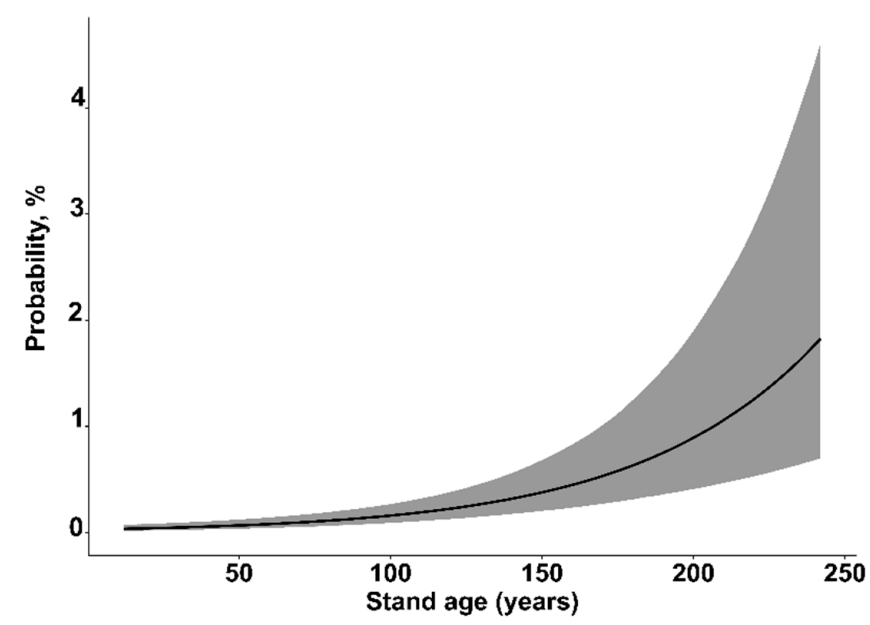

Figure 1. The influence of stand age on the probability of wind damage. The grey area represents the $\pm 95 \%$ credibility interval.

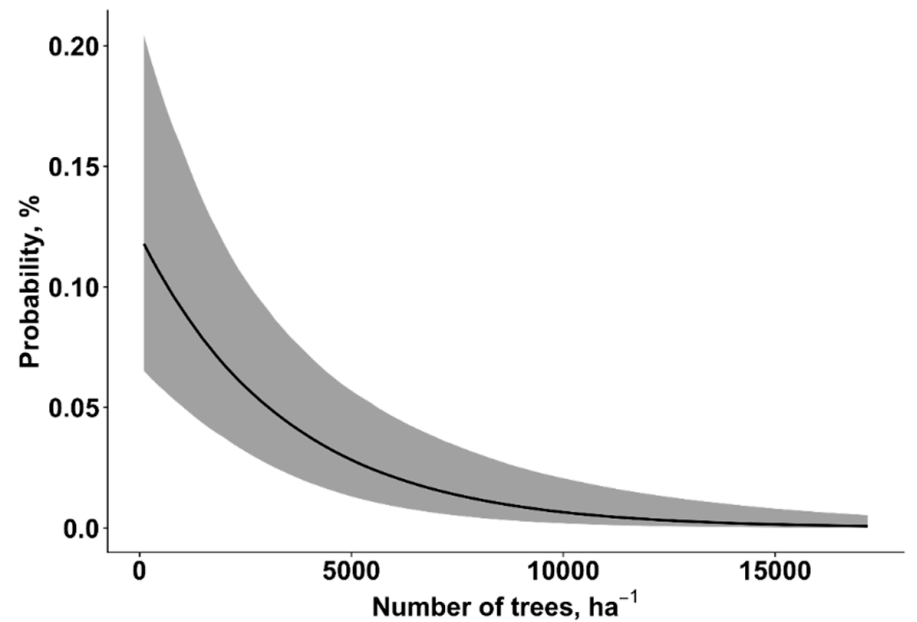

Figure 2. The influence of stand density $\left(\right.$ trees $\mathrm{ha}^{-1}$ ) on the probability of wind damage. The grey area represents the $\pm 95 \%$ credibility interval.

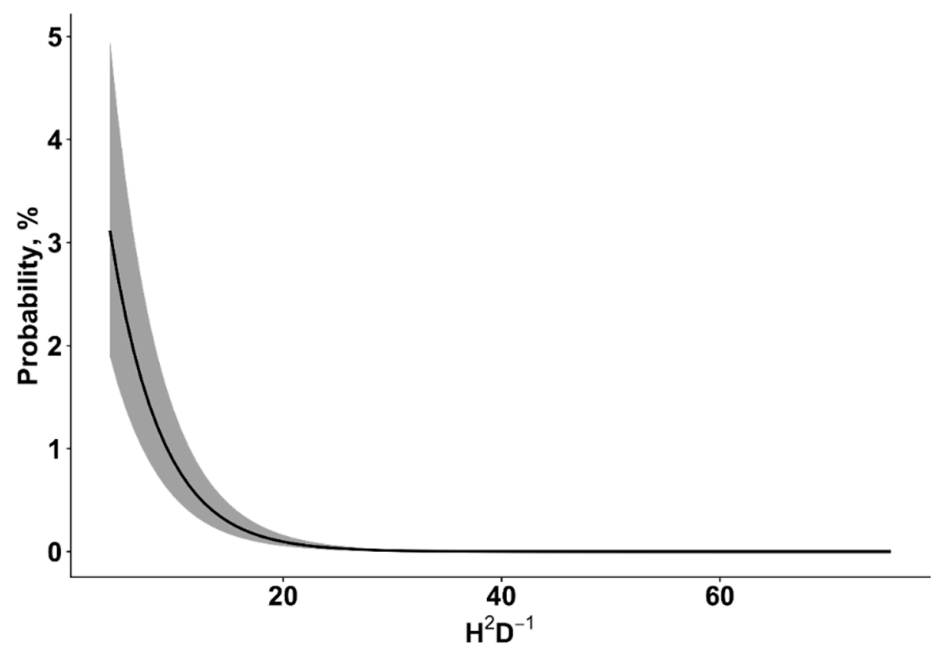

Figure 3. The influence of the slenderness ratio on the probability of wind damage. The grey area represents the $\pm 95 \%$ credibility interval. 
The LMER model showed that snapping height was significantly affected by two factors: stem damage intensity class $\left(\mathrm{F}_{2,705.89}=5.46 ; p\right.$-value $\left.=0.004\right)$ and the slenderness ratio $\left(\mathrm{F}_{1,638.36}=5.80\right.$; $p$-value $=0.016)$. Snapping height was significantly lower for trees that had animal damage with an intensity of $>30 \%$ (Table 4) (Figure 4) compared to those without damage. Similarly, the increasing slenderness ratio had a negative effect on snapping height (Figure 5).

Table 4. Parameter estimates of the fixed effects of the fitted snapping height model for Norway spruces. SE-standard error.

\begin{tabular}{ccccc}
\hline Explanatory Variables & Estimate & se & t-Value & $p$-Value \\
\hline Intercept & 0.522 & 0.029 & 18.00 & $<0.001$ \\
Stem damage intensity class $\leq 30 \%$ & -0.014 & 0.035 & -0.39 & 0.696 \\
Stem damage intensity class $>30 \%$ & -0.122 & 0.037 & -3.30 & 0.001 \\
$\mathrm{~h}^{2} / \mathrm{d}$ & -0.004 & 0.002 & -2.41 & 0.016 \\
\hline
\end{tabular}

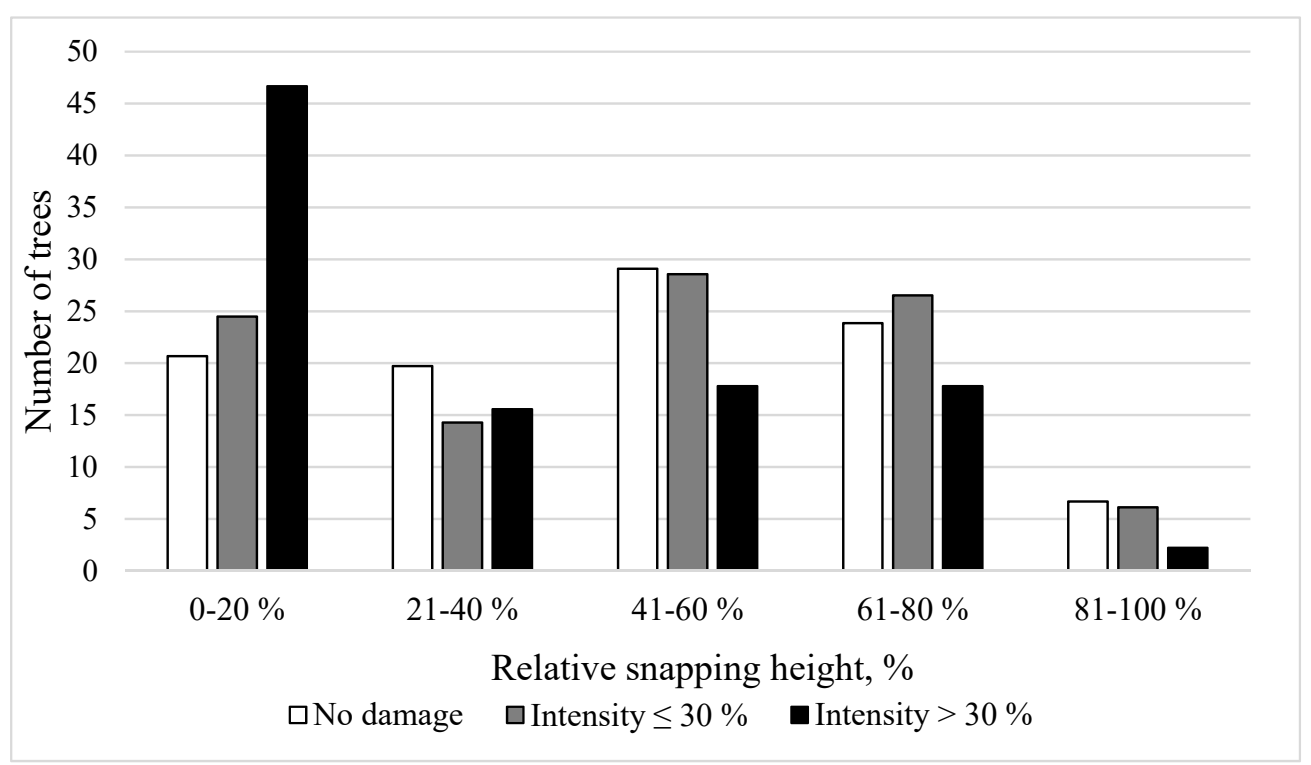

Figure 4. The percentage of trees by relative snapping height (\%) in different stem damage intensity classes (the relative damaged area of stem circumference).

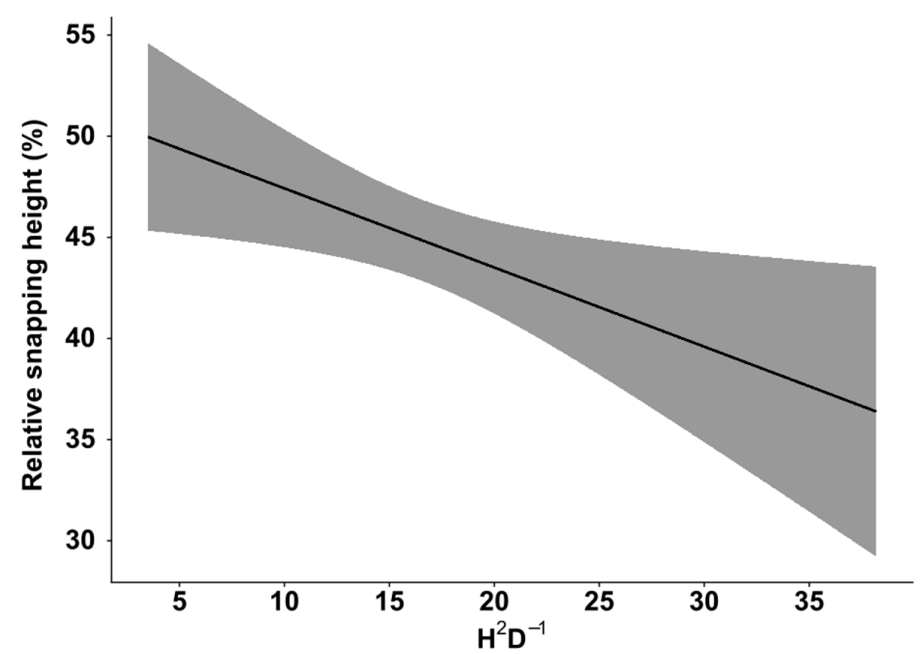

Figure 5. The influence of the slenderness ratio $\left(h^{2} / d\right)$ on relative snapping height $(\%)$. The grey area represents the $\pm 95 \%$ confidence interval. 


\section{Discussion}

This work summarises the influence of different tree- and stand-scale factors on the probability of wind damage on Norway spruces over 14 years in Latvia based on NFI sample plots. To the best of our knowledge, the current study presents the first systematic assessment of stem damage on the probability of wind damage and snapping height in hemiboreal forest zones.

We found a distinctive impact of stem and root-stump damage on the probability of wind damage. We assume that, due to stem wounds, Norway spruces lose vitality and are easily infected by decay-causing fungi. Studies have shown that especially larger wounds significantly decrease the growth vitality of Norway spruces $[33,50,62]$. The largest proportion $(70 \%)$ of stem damage were bark-stripping injuries. Yet considerably proportion (30\%) were caused by forest machinery. The studies show that irrespective of stem damage cause (bark-stripping or machinery), Norway spruce is easily infected by decay-causing fungi which deteriorate wood quality $[35,63,64]$. Nevertheless, studies have shown that such damage can significantly negatively affect tree wind stability $[38,65,66]$. The Norway spruce has a limited ability to protect sapwood from infection, which is linked to the poor creation of a protective barrier zone (compartmentalisation) around the wounded parts of the stem $[67,68]$. Studies have shown that even after one year since wound creation, disturbed sapwood could be detected $1 \mathrm{~m}$ above the wounded part in a 50-year-old Norway spruce stand in Germany [67]. Root-stump damage was either in wind-swayed trees or trees with damaged roots due to forest machinery. Wind-swayed trees, at the measurement time, were already partially damaged, with a high likelihood of a seriously weakened root anchorage, which considerable decrease tree wind stability [69].

In our study, the probability of wind damage increased with stand age (Figure 1). In Finland, similar observations were also reported: Gaps and old forest stands significantly increase the risk of wind damage at the landscape level $[19,22]$. The probability of wind damage increases as stands develop and accumulate higher standing volume [70]. The probability of wind damage decreased with increasing stand density: It decreased to close to zero when tree density exceeded 10,000 trees ha ${ }^{-1}$ (Figure 2). Such tree density can usually be observed in relatively young to middle-aged, unmanaged stands where the collective stand stability is high [71]. Our results showed that trees with a similar DBH but a higher mean height (higher values of $\mathrm{h}^{2} / \mathrm{d}$ ratio) were more susceptible to wind damage (Figure 3). Several other studies and a study conducted by Peltola et al. (2000) reported that trees with a larger DBH but with the same height were more resistant to uprooting and snapping than trees with the same height but a lower DBH $[42,43]$. It is important to take into account that stand density and the slenderness $\left(\mathrm{h}^{2} / \mathrm{d}\right)$ ratio is closely related to stand development and silviculture management practices [70,72]. In dense stands especially, when trees get older, the individual wind stability decreases. Several thinnings are carried out during rotation period to increase individual tree stability (decrease slenderness ratio). Hence, the correct timing of the thinnings and final harvest, as well as careful planning of clear-cuts at the landscape level, are important aspects in reducing the risk of wind damage [73,74].

The significantly higher probability of wind damage in Norway spruce-dominated stands (Table 3) is not surprising, as it is regarded as the most susceptible tree species to wind damage in boreal and hemiboreal forests $[13,42]$. Stands dominated by broadleaves (birch, aspen, grey alder, black alder) had a higher proportion of stem damaged Norway spruce trees than stands dominated by Scots pine, Norway spruce and common oak. Higher proportion of stem damages in broadleaved stands are likely explained by cervid forage preferences. Studies show that the main forage for cervids are broadleaved trees like birch, rowan (Sorbus aucuparia), aspen [75], and more. Browsing and bark-stripping damage has been observed mixed stands [76]. We assume that the probability of wind damage in these stands was likely increased by a higher proportion of stem damaged trees. Significantly lower probability of wind damage in stands dominated by Scots pine and common oak might be linked to lower proportion of stem damaged trees, as well as an overall higher wind stability of these tree species [22,42,77]. Studies have shown that an admixture of wind-firm tree species can reduce the vulnerability of wind damage in Norway spruce-dominate stands [71]. 
The amount of damage caused in forests not only depends on general characteristics of tree species but also on windstorm features, the regional wind climate, and soil types $[13,70]$. In our study, the highest probability of wind damage for Norway spruces was observed in mineral soils. Contrasting results were obtained following the "Gudrun" windstorm in 2005, when higher damage was observed in peat soils [13]. Similarly, following a single-storm event in Finland, greater damage was observed in soils where trees had shallow rooting systems [43]. In this study, we used NFI data from a decade-long period. Hence, indirectly, we assessed a long-term regional wind climate influence on Norway spruce. Therefore, likely damage occurrences and severity differ from the other studies which were based on a single exceptional windstorm event. Moreover, some parts of the wind-damaged stands could be missed by NFI data because of the timely carried out salvage-logging. Previous authors have also highlighted that conclusions based on single disturbance events should be treated cautiously [70]. Generally, trees on mineral soils grow better than in waterlogged and peat soils, hence more aboveground biomass (standing volume) is accumulated and a higher mean height is reached which considerably increases the probability of wind damage [42,70].

In our study, we modelled probability of wind damage for Norway spruce trees with DBH $>14 \mathrm{~cm}$. Although, young conifers are highly likely to suffer from browsing and bark-stripping damages [33,76]. Studies have shown that younger trees $(>10 \mathrm{~m})$ are less likely to suffer from wind damage [71], but more likely from snow and ice damage [78]. In the NFI data snow and ice damage is not separated from wind damage. Therefore, we did not include younger trees in our model, because of higher probability of snow and ice damage, which might compromise the results.

In our study, the most severely stem-damaged trees had significantly lower snapping height than trees with little or no damage (Figure 4). The observed pattern is likely linked to decreased wood strength caused by damage severity and highly possible subsequent wood infection by decay causing fungi, as discussed in the first paragraph of the discussion section. The wounded part of the stem for Norway spruces is usually desiccated, discoloured, and has a lower moisture content [67]; hence, wood strength is significantly reduced [79]. In our study, more than $45 \%$ of trees with severe damage snapped in the first $20 \%$ of the total stem height (Figure 4), indicating that snapping height occurs closer to the part with the lowest wood strength. The distribution of the relative snapping heights could be used to predict the potential recovered timber value [45]. Similarly, for bark-stripped Sitka spruces (Picea sitchensis), mean stiffness and the strength of the wood were significantly reduced close to the stem wound [50]. Furthermore, stem-damaged trees with a higher slenderness ratio will likely have a lower snapping height (Figure 5), which suggests that the previous management regime is an important influencing factor. Stem damage causes economic losses due to lower cut-log quality (decay or discolouration) $[50,68]$. A low snapping height can decrease the monetary value by up to $35 \%$ of the first cut log [45]. A low snapping height in combination with stem damage suggests that the quality of the first cut log will likely correspond to the category of fuelwood. The crucial challenge for silviculture systems in forests will be to minimise cervid damage without simultaneously compromising on wind stability.

\section{Conclusions}

Stem damage primarily caused by cervids had a significant impact on both the probability of wind damage as well as on the snapping height for Norway spruce. Hence, wind-caused damage in hemiboreal forests will be amplified by interactions with cervids and silvicultural practices, which enhance the increase in stem slenderness. Therefore, game management and stem protection, as well as timely implementation of precommercial thinnings, would not only reduce stem damage, but also increase the growth of the trees. Root and stem damages should be minimized during stand management operations by carefully planned execution and by limiting the number of interventions. Wind stability of a stand can be modified and increased during thinnings or selective cuts, when trees with lower individual wind stability, e.g., stem or root damage, or improper values of slenderness ratio, are 
removed. Further research could assess factors which increase the likelihood of stem damage by cervids, as well as estimate spatial associations and patterns of interactions between different disturbance agents.

Author Contributions: Conceptualization and idea, A.J. and G.S.; methodology, G.S. and J.D.; data statistics, D.E.; writing—original draft preparation, M.K. and G.S.; writing—review and editing, M.K., A.J., J.D., G.S., D.E.; All authors have read and agreed to the published version of the manuscript.

Funding: This research was funded by the European Regional Development Fund Project Development of decision support tool for the prognosis of storm damages in forest stands on peat soils (No 1.1.1.1/16/A/260).

Acknowledgments: We are very grateful to the four anonymous reviewers, for their thoughtful suggestions and comments which helped us to improve the manuscript.

Conflicts of Interest: The authors declare no conflict of interest.

\section{References}

1. Sommerfeld, A.; Senf, C.; Buma, B.; D'Amato, A.W.; Després, T.; Díaz-Hormazábal, I.; Fraver, S.; Frelich, L.E.; Gutiérrez, Á.G.; Hart, S.J.; et al. Patterns and drivers of recent disturbances across the temperate forest biome. Nat. Commun. 2018, 9, 4355. [CrossRef] [PubMed]

2. Seidl, R.; Thom, D.; Kautz, M.; Martin-Benito, D.; Peltoniemi, M.; Vacchiano, G.; Wild, J.; Ascoli, D.; Petr, M.; Honkaniemi, J.; et al. Forest disturbances under climate change. Nat. Clim. Chang. 2017, 7, 395-402. [CrossRef] [PubMed]

3. Thom, D.; Seidl, R. Natural disturbance impacts on ecosystem services and biodiversity in temperate and boreal forests. Biol. Rev. 2016, 91, 760-781. [CrossRef] [PubMed]

4. Seidl, R.; Schelhaas, M.-J.; Lexer, M.J. Unraveling the drivers of intensifying forest disturbance regimes in Europe. Glob. Chang. Biol. 2011, 17, 2842-2852. [CrossRef]

5. Gregow, H.; Laaksonen, A.; Alper, M.E. Increasing large scale windstorm damage in Western, Central and Northern European forests, 1951-2010. Sci. Rep. 2017, 7, 46397. [CrossRef] [PubMed]

6. Seidl, R.; Rammer, W. Climate change amplifies the interactions between wind and bark beetle disturbances in forest landscapes. Landsc. Ecol. 2017, 32, 1485-1498. [CrossRef] [PubMed]

7. Anderegg, W.R.; Anderegg, L.D.L.; Kerr, K.L.; Trugman, A.T. Widespread drought - induced tree mortality at dry range edges indicates that climate stress exceeds species' compensating mechanisms. Glob. Chang. Biol. 2019, 25, 3793-3802. [CrossRef]

8. Millar, C.I.; Stephenson, N.L. Temperate forest health in an era of emerging megadisturbance. Science 2015, 349, 823-826. [CrossRef]

9. Schelhaas, M.-J.; Nabuurs, G.-J.; Schuck, A. Natural disturbances in the European forests in the 19th and 20th centuries. Glob. Chang. Biol. 2003, 9, 1620-1633. [CrossRef]

10. Mason, B.; Valinger, E. Managing forests to reduce storm damage. In Living with the Storm Damage; Gardiner, E., Schuck, A., Schelhaas, M.-J., Orazio, C., Blennow, K., Nicoll, B., Eds.; European Forest Institute: Joensuu, Finland, 2013; pp. 87-97.

11. Suvanto, S.; Henttonen, H.M.; Nöjd, P.; Mäkinen, H. Forest susceptibility to storm damage is affected by similar factors regardless of storm type: Comparison of thunder storms and autumn extra-tropical cyclones in Finland. For. Ecol. Manag. 2016, 381, 17-28. [CrossRef]

12. Schuck, A.; Schelhaas, M.-J. Storm damage in Europe-An overview. In Living with the Storm Damage; Gardiner, E., Schuck, A., Schelhaas, M.-J., Orazio, C., Blennow, K., Nicoll, B., Eds.; European Forest Institute: Joensuu, Finland, 2013; pp. 15-25.

13. Donis, J.; Kitenberga, M.; Snepsts, G.; Dubrovskis, E.; Jansons, A. Factors affecting windstorm damage at the stand level in hemiboreal forests in Latvia: Case study of 2005 winter storm. Silva Fenn. 2018, 52, 1-8. [CrossRef]

14. Venäläinen, A.; Zeng, H.; Peltola, H.; Talkkari, A.; Strandman, H.; Wang, K.; Kellomäki, S. Simulations of the influence of forest management on wind climate on a regional scale. Agric. For. Meteorol. 2004, 123, 149-158. [CrossRef]

15. Zeng, H.; Peltola, H.; Väisänen, H.; Kellomäki, S. The effects of fragmentation on the susceptibility of a boreal forest ecosystem to wind damage. For. Ecol. Manage. 2009, 257, 1165-1173. [CrossRef] 
16. Gardiner, B.A.; Berry, P.; Moulia, B. Review: Wind impacts on plant growth, mechanics and damage. Plant Sci. 2016, 245, 94-118. [CrossRef] [PubMed]

17. Peltola, H.; Kellomäki, S. A mechanistic model for calculating windthrow and stem breakage of Scots pines at stand edge. Silva Fenn. 1993, 27, 99-111. [CrossRef]

18. Dupont, S.; Ikonen, V.-P.; Väisänen, H.; Peltola, H. Predicting tree damage in fragmented landscapes using a wind risk model coupled with an airflow model. Can. J. For. Res. 2015, 45, 1065-1076. [CrossRef]

19. Zeng, H.; Garcia-Gonzalo, J.; Peltola, H.; Kellomäki, S. The effects of forest structure on the risk of wind damage at a landscape level in a boreal forest ecosystem. Ann. For. Sci. 2009, 67, 111. [CrossRef]

20. Simard, M.; Omme, W.R.; Griffin, J.M.; Turner, M.G. Do mountain pine beetle outbreaks change the probability of active crown fire in lodgepole pine forests? Ecol. Monogr. 2011, 81, 3-24. [CrossRef]

21. Buma, B. Disturbance interactions: Characterization, prediction, and the potential for cascading effects. Ecosphere 2015, 6, 70. [CrossRef]

22. Peltola, H.; Kellomäki, S.; Väisänen, H.; Ikonen, V.-P. A mechanistic model for assessing the risk of wind and snow damage to single trees and stands of Scots pine, Norway spruce, and birch. Can. J. For. Res. 1999, 29, 647-661. [CrossRef]

23. Schroeder, L.M. Tree Mortality by the Bark Beetle Ips typographus (L.) in storm-disturbed stands. Integr. Pest Manag. Rev. 2001, 6, 169-175. [CrossRef]

24. Csilléry, K.; Kunstler, G.; Courbaud, B.; Allard, D.; Lassègues, P.; Haslinger, K.; Gardiner, B.A. Coupled effects of wind-storms and drought on tree mortality across 115 forest stands from the Western Alps and the Jura mountains. Glob. Chang. Biol. 2017, 23, 5092-5107. [CrossRef] [PubMed]

25. Gregow, H.; Peltola, H.; Laapas, M.; Saku, S.; Venäläinen, A. Combined Occurrence of Wind, Snow Loading and Soil Frost with Implications for Risks to Forestry in Finland under the Current and Changing Climatic Conditions. Silva Fenn. 2011, 45, 35-54. [CrossRef]

26. Heinonen, T.; Pukkala, T.; Ikonen, V.P.; Peltola, H.; Gregow, H.; Venäläinen, A. Consideration of strong winds, their directional distribution and snow loading in wind risk assessment related to landscape level forest planning. For. Ecol. Manage. 2011, 261, 710-719. [CrossRef]

27. Vasiliauskas, R.; Stenlid, J.; Johansson, M. Fungi in bark peeling wounds of Picea abies in central Sweden. Eur. J. Plant Pathol. 1996, 26, 285-296. [CrossRef]

28. Arhipova, N.; Gaitnieks, T.; Donis, J.; Stenlid, J.; Vasaitis, R. Butt rot incidence, causal fungi, and related yield loss in Picea abies stands of Latvia. Can. J. For. Res. 2011, 41, 2337-2345. [CrossRef]

29. Schulze, E.D.; Bouriaud, O.; Wäldchen, J.; Eisenhauer, N.; Walentowski, H.; Seele, C.; Heinze, E.; Pruschitzki, U.; Dănilă, G.; Marin, G.; et al. Ungulate browsing causes species loss in deciduous forests independent of community dynamics and sil- vicultural management in Central and Southeastern Europe. Ann. For. Res. 2014, 57, 267-288. [CrossRef]

30. Borkowski, J.; Banul, R.; Jurkiewicz, J.; Hołdyński, C.; Świeczkowska, J.; Nasiadko, M.; Załuski, D. High density of keystone herbivore vs. conservation of natural resources: Factors affecting red deer distribution and impact on vegetation in Słowiński. For. Ecol. Manage. 2019, 450, 117503. [CrossRef]

31. Baumanis, J.; Runǵis, E.D.; Gailīte, A.; Gaile, A.; Done, G.; Lūkins, M.; Howlett, S.J.; Ozolinšs, J. Genetic Structure of Red Deer (Cervus elaphus L.) A Review of the Population and its Reintroduction in Latvia. Balt. For. 2018, 24, 296-303.

32. Bragina, E.V.; Ives, A.R.; Pidgeon, A.M.; Balčiauskas, L.; Csányi, S.; Khoyetskyy, P.; Kysucká, K.; Lieskovsky, J.; Ozolins, J.; Randveer, T.; et al. Wildlife population changes across Eastern Europe after the collapse of socialism. Front. Ecol. Environ. 2018, 16,77-81. [CrossRef]

33. Cukor, J.; Vacek, Z.; Linda, R.; Vacek, S.; Marada, P.; Šimůnek, V.; Havránek, F. Effects of Bark Stripping on Timber Production and Structure of Norway Spruce Forests in Relation to Climatic Factors. Forests 2019, 10, 320. [CrossRef]

34. Metslaid, M.; Palli, T.; Randveer, T.; Sims, A.; Jõgiste, K. The condition of Scots pine stands in Lahemaa National Park, Estonia 25 years after browsing by moose (Alces alces). Boreal Environ. Res. 2013, 18, $25-34$.

35. Vasiliauskas, R. Damage to trees due to forestry operations and its pathological significance in temperate forests: A literature review. Forestry 2001, 74, 319-336. [CrossRef]

36. Metslaid, M.; Köster, K.; Jõgiste, K.; Randveer, T.; Voolma, K.; Moser, K. The Effect of Simulated Bark Stripping by Moose on Scots Pine Height Growth: An Experimental Treatment. Balt. For. 2013, 19, 61-66. 
37. Gaitnieks, T.; Zaluma, A.; Kenigsvalde, K.; Klavina, D.; Brauners, I.; Piri, T. Susceptibility of Small-Diameter Norway Spruce Understory Stumps to Heterobasidion Spore Infection. Forests 2019, 10, 521. [CrossRef]

38. Honkaniemi, J.; Lehtonen, M.; Väisänen, H.; Peltola, H. Effects of wood decay by Heterobasidion annosum on the vulnerability of Norway spruce stands to wind damage: A mechanistic modelling approach. Can. J. For. Res. 2017, 47, 777-787. [CrossRef]

39. Gardiner, B.A.; Blennow, K.; Carnus, J.-M.; Fleischer, M.; Ingemarson, F.; Landmann, G.; Lindner, M.; Marzano, M.; Nicoll, B.C.; Orazio, C.; et al. Destructive storms in European Forests: Past and Forthcoming Impacts. Final Report to EC DG Environment. 2010. Available online: http://ec.europa.eu/environment/ forests/fprotection.htm (accessed on 5 February 2020).

40. Hanewinkel, M.; Peyron, J.L. The economic impact of storms. In Living with the Storm Damage; Gardiner, E., Schuck, A., Schelhaas, M.-J., Orazio, C., Blennow, K., Nicoll, B., Eds.; European Forest Institute: Joensuu, Finland, 2013; pp. 55-63.

41. Kärhä, K.; Anttonen, T.; Poikela, A.; Palander, T.; Laurén, A.; Peltola, H.; Nuutinen, Y. Evaluation of salvage logging productivity and costs in windthrown Norway spruce-dominated forests. Forests 2018, 9, 280. [CrossRef]

42. Peltola, H.; Kellomäki, S.; Hassinen, A.; Granander, M. Mechanical stability of Scots pine, Norway spruce and birch: An analysis of tree-pulling experiments in Finland. For. Ecol. Manage. 2000, 135, 143-153. [CrossRef]

43. Zubizarreta-Gerendiain, A.; Pellikka, P.; Garcia-Gonzalo, J.; Ikonen, V.P.; Peltola, H. Factors affecting wind and snow damage of individual trees in a small management unit in Finland: Assessment based on inventoried damage and mechanistic modelling. Silva Fenn. 2012, 46, 181-196. [CrossRef]

44. Nagel, T.A.; Diaci, J. Intermediate wind disturbance in an old-growth beech-fir forest in southeastern Slovenia. Can. J. For. Res. 2006, 36, 629-638. [CrossRef]

45. Dubrovskis, E.; Donis, J.; Racenis, E. Wind-induced stem breakage height effect on potentially recovered timber value: Case study of the Scots pine (Pinus sylvestris L.) in Latvia. For. Stud. 2018, 69, 24-32. [CrossRef]

46. Hart, E.; Sim, K.; Kamimura, K.; Meredieu, C.; Guyon, D.; Gardiner, B.A. Use of machine learning techniques to model wind damage to forests. Agric. For. Meteorol. 2019, 265, 16-29. [CrossRef]

47. Gardiner, B.A.; Byrne, K.; Hale, S.E.; Kamimura, K.; Mitchell, S.J.; Peltola, H.; Ruel, J.C. A review of mechanistic modelling of wind damage risk to forests. Forestry 2008, 81, 447-463. [CrossRef]

48. Kamimura, K.; Gardiner, B.A.; Dupont, S.; Guyon, D.; Meredieu, C. Mechanistic and statistical approaches to predicting wind damage to individual maritime pine (Pinus pinaster) trees in forests. Can. J. For. Res. 2015, 46, 88-100. [CrossRef]

49. Jacobsen, M.K. History and Principles of Close to Nature Forest Management: A Central European Perspective. In Textbook 2-Tools for Preserving Woodland Biodiversity; Forfang, A.S., Marciau, R., Paltto, H., Andersson, L., Tardy, B., Eds.; Nature Conservation Exchange Experience, NACONEX, Pro-Natura: Göteborg, Sweden, 2001; pp. 56-60. Available online: http://www.pro-natura.net/naconex/news5/E2_11.pdf (accessed on 15 December 2019).

50. Welch, D.; Scott, D. An estimate of timber degrade in Sitka spruce due to bark stripping by deer in a Scottish plantation. Forestry 2008, 81, 489-497. [CrossRef]

51. Ahti, T.; Hämet-ahti, L.; Jalas, J. Vegetation zones and their sections in northwestern Europe. Ann. Bot. Fenn. 1968, 5, 169-211.

52. Silava Methodology of National Forest Inventory. Available online: http://www.silava.lv/userfiles/file/ Nacionalais\%20meza\%20monitorings/Me\%C5\%BEa\%20resursu\%20monitoringa\%20metodika\%2026_04_ 2013.pdf (accessed on 3 February 2020). (In Latvian).

53. Gschwantner, T.; Alberdi, I.; Balázs, A.; Bauwens, S.; Bender, S.; Borota, D.; Bosela, M.; Bouriaud, O.; Cañellas, I.; Donis, J.; et al. Harmonisation of stem volume estimates in European National Forest Inventories. Ann. For. Sci. 2019, 76, 1-23. [CrossRef]

54. Díaz-Yáñez, O.; Mola-Yudego, B.; Eriksen, R.; González-Olabarria, J.R. Assessment of the main natural disturbances on Norwegian forest based on 20 years of national inventory. PLoS ONE 2016, 11, e0161361. [CrossRef]

55. Wulff, S.; Roberge, C.; Ringvall, A.H.; Holm, S.; Ståhl, G. On the possibility to monitor and assess forest damage within large scale monitoring programmes. Silva Fenn. 2013, 47, 1000. [CrossRef]

56. Bušs, K. Fundamentals of Forest Classification in Latvia SSR; LRZTIPI: Rīga, Latvia, 1976; p. 24. (In Latvian) 
57. R CoreTeam. R: A Language and Environment for Statistical Computing; R Foundation for Statistical Computing: Vienna, Austria, 2019; Available online: https://www.R-project.org/ (accessed on 1 March 2020).

58. Bürkner, P.C. Advanced Bayesian Multilevel Modeling with the R Package brms. R J. 2018, 10, $395-411$. [CrossRef]

59. Bates, D.; Mächler, M.; Bolker, B.M.; Walker, S.C. Fitting Linear Mixed-Effects Models Using lme4. J. Stat. Softw. 2015, 67, 1-48. [CrossRef]

60. Kuznetsova, A.; Brockhoff, P.B.; Christensen, R.H.B. lmerTest Package: Tests in Linear Mixed Effects Models. J. Stat. Softw. 2017, 82, 26. [CrossRef]

61. Lenth, R. Emmeans: Estimated Marginal Means, aka Least-Squares Means. R Package Version 1.4.4. Available online: https://CRAN.R-project.org/package=emmeans (accessed on 5 March 2020).

62. Priedītis, A.; Howlett, S.J.; Baumanis, J.; Bagrade, G.; Done, G.; Jansons, Ā.; Neimane, U.; Ornicāns, A.; Stepanova, A.; Šmits, A.; et al. Quantification of Deer Browsing in Summer and Its Importance for Game Management in Latvia. Balt. For. 2017, 23, 423-431.

63. Burneviča, N.; Jansons, Â.; Zaluma, A.; Klavina, D.; Jansons, J.; Gaitnieks, T. Fungi Inhabiting Bark Stripping Wounds Made by Large Game on Stems of Picea abies (L.) Karst. in Latvia. Balt. For. 2016, 22, 2-7.

64. Metzler, B.; Hecht, U.; Nill, M.; Brüchert, F.; Fink, S.; Kohnle, U. Comparing Norway spruce and silver fir regarding impact of bark wounds. For. Ecol. Manag. 2012, 274, 99-107. [CrossRef]

65. Giordano, L.; Nicolotti, G.; Gonthier, P. Effect of Heterobasidion annosum s.l. Root and Butt Rots on the Stability of Norway Spruce: An Uprooting Test. In Proceedings of the XIII International Conference on Root and Butt Root of Forest Trees. Firenze (FI)—S. Martino di Castrozza (TN), Trento, Italy, 4-10 September 2012; Capretti, P., Comparini, P., Garbelotto, M., la Porta, N., Santini, A., Eds.; Unive: Venice, Italy, 2012; pp. 247-250.

66. Krisans, O.; Matisons, R.; Burnevica, N.; Bruna, L.; Elferts, D.; Kalvane, L.; Jansons, A. Presence of Root Rot Reduces Stability of Norway Spruce (Picea abies): Results of Static Pulling Tests in Latvia. Forests 2020, 11, 416. [CrossRef]

67. Brüchert, F.; Šeho, M.; Kohnle, U. Impact of bark wounds on sapwood in Norway spruce and silver fir. Eur. J. For. Res. 2017, 136, 957-969. [CrossRef]

68. Mäkinen, H.; Hallaksela, A.-M.; Isomäki, A. Increment and decay in Norway spruce and Scots pine after artificial logging damage. Can. J. For. Res. 2007, 37, 2130-2141. [CrossRef]

69. Stokes, A. Responses of Young Trees To Wind: Effects on Root Architecture and Anchorage Strength. Ph.D. Thesis, University of York, York, UK, 1994; p. 162.

70. Valinger, E.; Fridman, J. Factors affecting the probability of windthrow at stand level as a result of Gudrun winter storm in southern Sweden. For. Ecol. Manag. 2011, 262, 398-403. [CrossRef]

71. Schütz, J.-P.; Götz, M.; Schmid, W.; Mandallaz, D. Vulnerability of spruce (Picea abies) and beech (Fagus sylvatica) forest stands to storms and consequences for silviculture. Eur. J. For. Res. 2006, 125, 291-302. [CrossRef]

72. Bošel'a, M.; Konôpka, B.; Šebeň, V.; Vladovič, J.; Tobin, B. Modelling height to diameter ratio-An opportunity to increase Norway spruce stand stability in the Western Carpathians Modelovanie štíhlostného kvocientu-Možnosti zvýšenia statickej stability smrekových porastov v Západných Karpatoch. Cent. Eur. For. J. 2014, 60, 71-80.

73. Zeng, H.; Pukkala, T.; Peltola, H. The use of heuristic optimization in risk management of wind damage in forest planning. For. Ecol. Manag. 2007, 241, 189-199. [CrossRef]

74. Peltola, H.; Ikonen, V.; Gregow, H.; Strandman, H.; Kilpeläinen, A.; Venäläinen, A.; Kellomäki, S. Impacts of climate change on timber production and regional risks of wind-induced damage to forests in Finland. For. Ecol. Manag. 2010, 260, 833-845. [CrossRef]

75. Wam, H.K.; Hjeljord, O. Moose summer and winter diets along a large scale gradient of forage availability in southern Norway. Eur. J. Wildl. Res. 2010, 56, 745-755. [CrossRef]

76. Díaz-Yáñez, O.; Mola-Yudego, B.; González-Olabarria, J.R. What variables make a forest stand vulnerable to browsing damage occurrence? Silva Fenn. 2017, 51, 1-11. [CrossRef]

77. Albrecht, A.; Hanewinkel, M.; Bauhus, J.; Kohnle, U. How does silviculture affect storm damage in forests of south-western Germany? Results from empirical modeling based on long-term observations. Eur. J. For. Res. 2012, 131, 229-247. [CrossRef] 
78. Kuboyama, H.; Oka, H. Climate Risks and Age-related Damage Probabilities-Effects on the Economically Optimal Rotation Length for Forest Stand Management in Japan. Silva Fenn. 2000, 34, 155-166. [CrossRef]

79. Wood, C.J. Understanding wind forces on trees. In Wind and Trees; Coutts, M.P., Grace, J., Eds.; Cambridge University Press: Cambridge, UK, 1995; pp. 133-164.

(C) 2020 by the authors. Licensee MDPI, Basel, Switzerland. This article is an open access article distributed under the terms and conditions of the Creative Commons Attribution (CC BY) license (http://creativecommons.org/licenses/by/4.0/). 